\title{
Degradation of myofibrils in cultured yellowtail Seriola quinqueradiata burnt meat: effects of a myofibril-bound EDTA-sensitive protease
}

\author{
Xiao Liang • Asami Yoshida $\cdot$ Kiyoshi Osatomi • \\ Yajun Wang $\cdot$ Min-Jie Cao $\cdot$ Kenji Hara
}

Received: 4 July 2011/Accepted: 16 October 2011/Published online: 19 November 2011

(C) The Author(s) 2011. This article is published with open access at Springerlink.com

\begin{abstract}
Burnt meat" is a term used to describe the white (pale, grainy, exudative) muscle of yellowtail or tuna. It (with lightness parameter, $L^{*} \geq 55$ ) was observed after $2 \mathrm{~h}$ storage in the suffocate in air (SA) $29^{\circ} \mathrm{C}$ group and after $4 \mathrm{~h}$ storage in the spinal cord destruction (SCD) $29^{\circ} \mathrm{C}$ group. In the SA $17^{\circ} \mathrm{C}$ group, burnt meat was also observed after $4 \mathrm{~h}$ storage. In contrast, the meat in the SCD $17^{\circ} \mathrm{C}$ group was normal until after $12 \mathrm{~h}$ storage. The myosin heavy chain (MHC) was more degraded than the other myofibrillar proteins, and some protein bands increased in the burnt meat. The protease that leads to the degradation of MHC was investigated using myofibrils from the meat. EDTA completely suppressed the degradation, indicating that a myofibril-bound EDTA-sensitive protease (MBESP) may exist in yellowtail muscle and this caused the degradation of MHC. The optimum $\mathrm{pH}$ and temperature of MBESP in yellowtail were 5.0 and $50-60^{\circ} \mathrm{C}$, respectively.
\end{abstract}

X. Liang · Y. Wang

Graduate School of Science and Technology,

Nagasaki University, Nagasaki 852-8521, Japan

A. Yoshida $\cdot$ K. Osatomi $\cdot$ K. Hara $(\bowtie)$

Graduate School of Fisheries Science and Environmental

Studies, Nagasaki University, Nagasaki 852-8521, Japan

e-mail: hara@nagasaki-u.ac.jp

Y. Wang

Department of Bacteriology, Osaka City University

Graduate School of Medicine, Osaka 545-8585, Japan

M.-J. Cao

College of Biological Engineering, The Key Laboratory of Science and Technology for Aquaculture and Food Safety, Jimei University, Xiamen 361021, China
Keywords Burnt meat · Yellowtail · Myofibril proteolysis - Myofibril-bound protease - EDTA-sensitive protease

\section{Introduction}

The yellowtail Seriola quinqueradiata is one of the most important fish among cultured species in Japan. According to data from the Fisheries Agency of Japan, cultured yellowtail accounted for approximately $70 \%$ of total yellowtail production in 2006. In Japan, yellowtail meat is traditionally and popularly eaten raw as sashimi. However, variation in the quality of yellowtail raw meat has been recently observed during the summer time, and this is referred to as "burnt meat" [1].

"Burnt meat" is a term used by aquaculturists and commercial buyers to describe the white coloration of yellowtail or tuna muscle. It is pale, grainy and exudative, and is considered unsuitable for consumption as raw meat. Previous studies demonstrated that the burnt meat appearance is also observed in pork and meat of other fish species, and these researches suggested that the deterioration in the quality of burnt meat may be caused by high temperature in the environment, low ultimate muscle $\mathrm{pH}$ and slaughter methods [2-5]. In addition, myofibrillar proteins of the pale, soft and exudative (PSE) meat broke down with aging [6-8]. Konagaya and Konagaya [9] reported that approximately $60-90 \%$ of myofibrillar proteins were denatured in burnt red-meat fish. Mora et al. [1] investigated the characteristics of the burnt meat of cultured yellowtail and found that the ultimate decrease in muscle $\mathrm{pH}$ and the degradation of the myofibrillar proteins may lead to the burnt meat appearance in yellowtail. 
In marine and freshwater fish, degradation of myofibrillar proteins is also the main cause of the modori phenomenon (thermal gel degradation of fish jelly products at around $55^{\circ} \mathrm{C}$ ) during the manufacturing process $[10,11]$. Several studies have shown that the different types of endogenous protease, such as cathepsins [12-16], aspartic acid proteases [17] or serine proteinases [18, 19], especially the myofibril-bound serine proteinases [20, 21], led to the degradation of myofibrillar proteins in fish meat.

In this study, the authors investigated the degradation of myofibrillar proteins, especially the degradation of the myosin heavy chain (MHC), of burnt meat of cultured yellowtail with different breeding water temperatures (17 and $29^{\circ} \mathrm{C}$ ) and different slaughter methods. Furthermore, the protease that leads to the degradation of $\mathrm{MHC}$ was also investigated to clarify the relationship between the degradation of myofibrillar proteins and proteases in burnt meat of cultured yellowtail.

\section{Materials and methods}

\section{Materials}

Yellowtail Seriola quinqueradiata (average fork length $68.85 \pm 4.50 \mathrm{~cm}$, average weight $5.40 \pm 0.60 \mathrm{~kg}$ ) samples were obtained from a culture farm in Nagasaki Prefecture, Japan, during the summer and winter periods. Water temperatures at the sampling site in summer and in winter were 29 and $17^{\circ} \mathrm{C}$, respectively. Fish kept at $17^{\circ} \mathrm{C}$ were used as the control during the assays.

\section{Slaughter methods and sampling}

Two slaughter methods, including spinal cord destruction (SCD) and suffocation in air (SA), were conducted following the procedure described by Mora et al. [1]. After slaughtering, the viscera of the fish were removed, and the heads and tails were cut off. Fish blocks were wrapped up in Kimtowels containing $10 \mathrm{mM}$ sodium azide solution to avoid contamination by microorganisms, and then placed in plastic bags and stored at $30^{\circ} \mathrm{C}$. Sampling was made at 0 (immediately after slaughtering), 2, 4, 6, 12 and $24 \mathrm{~h}$ of storage. Dorsal ordinary muscle samples were cut into 1-cm-thick slices for measurement of color and $\mathrm{pH}$, and for analysis of the degradations of myofibrillar proteins.

Evaluation of meat quality

One-centimeter-thick slices of dorsal ordinary muscles (per sampling time) were used for color measurement. The color of sliced muscles was measured with a Minolta CR-200b color chromameter (Konica-Minolta, Tokyo,
Japan). Color variations were obtained as $L^{*}$ (lightness), $a^{*}$ (red-green chromaticity) and $b^{*}$ (yellow-blue chromaticity) [22]. The measurement was carried out four times for each sample, and the values were averaged. In addition, 1-g samples of the ordinary muscle (per sampling time) were homogenized in $9 \mathrm{ml}$ of distilled water. After homogenization, the $\mathrm{pH}$ value of the homogenate was immediately measured using a SevenEasy S20 pH meter (MettlerToledo International Inc., Tokyo, Japan).

Preparation of myofibrils from muscle samples

Each 50-mg muscle sample (0-24 h) was minced and homogenized with six volumes of ice-cold buffer $(0.1 \mathrm{M}$ $\mathrm{KCl}, 40 \mathrm{mM}$ boric acid, $50 \mathrm{mM}$ sodium borate, $\mathrm{pH} 7.0$ ) using a Physcotron NS-50 homogenizer (Microtec Co., Ltd., Funabashi, Japan). The homogenization process was performed on ice, and the operation was repeated three times (30 s each time and an interval of $2 \mathrm{~min}$ ) and centrifuged at 9,000 rpm at $4^{\circ} \mathrm{C}$ for $20 \mathrm{~min}$. The supernatant was discarded, and the pellet was collected and resuspended in buffer. Myofibril pellets of cultured yellowtail were obtained after repeating the above procedure three times. Myofibrils were mixed with $1 \mathrm{ml}$ of SDS buffer (20 mM Tris-HCl, pH 8.0, $8 \mathrm{M}$ urea, 2\% sodium dodecylsulfate, $0.02 \%$ bromphenol blue and $7.5 \%$ 2-mercaptoethanol) and heated in boiling water for $5 \mathrm{~min}$. The protein concentration of myofibrils was determined by the method of Lowry et al. [23] after proper dilution. Bovine serum albumin was used as a standard.

Sodium dodecylsulfate polyacrylamide gel electrophoresis (SDS-PAGE) analysis

SDS-PAGE was performed under reducing conditions with $8,8.5$ or $5-15 \%$ gels according to the method of Laemmli [24]. After electrophoresis, protein bands were visually detected by staining with Coomassie Brilliant Blue R-250 (CBB).

Inhibition of myofibrillar protein degradation using different protease inhibitors

The inhibiting effects of different kinds of protease inhibitors on the degradation myofibrillar proteins were further investigated to identify active proteases. Myofibrils used were isolated from muscles of newly slaughtered SCD groups. The experiment was performed using $5 \mathrm{mg}$ myofibril suspended in $50 \mathrm{mM}$ acetic acid-sodium acetate buffer ( $\mathrm{pH} 5.8$, the $\mathrm{pH}$ values of yellowtail burnt meat) containing different types of protease inhibitors (Pefabloc SC, E-64, pepstatin A, EDTA, o-phenanthroline and phosphoramidon). The mixture was incubated at $30^{\circ} \mathrm{C}$ for 
$12 \mathrm{~h}$, and effects of inhibitors on myofibrillar protein degradation were detected by SDS-PAGE using $8 \%$ polyacrylamide gels.

Effects of $\mathrm{pH}$ and temperature on the degradation of myofibrillar proteins

The effect of $\mathrm{pH}$ (from 1.5 to 9.0) on the degradation of myofibrillar protein was determined at $37^{\circ} \mathrm{C}$ by using $0.1 \mathrm{M}$ incubation buffers: $\mathrm{HCl}-$ sodium acetate buffer $(\mathrm{pH}$ 1.5-3.0), acetic acid-sodium acetate buffer ( $\mathrm{pH} 4.0-6.0$ ) and Tris- $\mathrm{HCl}$ buffer (7.0-9.0). Myofibrils were isolated from the muscle of the newly slaughtered SCD $17^{\circ} \mathrm{C}$ group. Mixtures were incubated for $12 \mathrm{~h}$, and the effect of $\mathrm{pH}$ on the degradation was analyzed by SDS-PAGE using $8.5 \%$ polyacrylamide gels. The effect of temperatures (from 20 to $70^{\circ} \mathrm{C}$ ) on the degradation of myofibrillar protein, which was incubated for $12 \mathrm{~h}$ in $0.1 \mathrm{M}$ acetic acid-sodium acetate buffer ( $\mathrm{pH}$ 5.0), was analyzed by SDS-PAGE.

\section{Results}

Changes in muscle color

The color of yellowtail muscle after it was slaughtered was brilliant pink and was transparent in appearance, while the burnt meat muscle was white in color and turbid in appearance. Changes in lightness $\left(L^{*}\right)$ on yellowtail ordinary muscle from the two breeding temperatures and two slaughter methods during storage at $30^{\circ} \mathrm{C}$ are shown in Fig. 1. Muscles with lightness values of $L^{*} \geq 55$ [1] were evaluated as burnt meat. The $L^{*}$ value of the SA $29^{\circ} \mathrm{C}$ group was 60 within $2 \mathrm{~h}$, indicating that the burnt meat phenomenon had progressed.

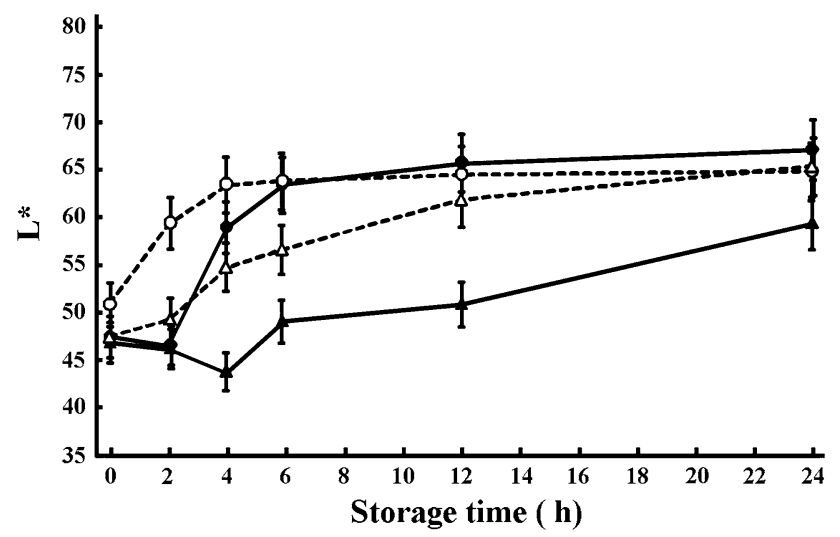

Fig. 1 Changes in lightness $L^{*}$ of the ordinary muscle of yellowtail from two breeding temperatures and two slaughter methods during storage at $30^{\circ} \mathrm{C}$. Filled circles SCD $29^{\circ} \mathrm{C}$; open circles SA $29^{\circ} \mathrm{C}$; closed triangles SCD $17^{\circ} \mathrm{C}$; open triangles SA $17^{\circ} \mathrm{C}$. Data are means $( \pm \mathrm{SD})$ of three replicates
In the SCD $29^{\circ} \mathrm{C}$ group, the burnt meat was also observed within $4 \mathrm{~h}$, and the $L^{*}$ value was 59 . In the case of the SA $17^{\circ} \mathrm{C}$ group, the $L^{*}$ value gradually rose post-mortem, and the burnt meat appeared at $4 \mathrm{~h}$. In the $\operatorname{SCD} 17^{\circ} \mathrm{C}$ group, the $L^{*}$ value showed no significant change until $12 \mathrm{~h}$, and the $L^{*}$ value was 55 after $24 \mathrm{~h}$ storage.

Changes in ultimate muscle $\mathrm{pH}$

Changes in ultimate muscle $\mathrm{pH}$ of yellowtail ordinary muscle from the two breeding temperatures and two slaughter methods during storage at $30^{\circ} \mathrm{C}$ are shown in Fig. 2. In the $\mathrm{SCD} 29^{\circ} \mathrm{C}$ group, the $\mathrm{pH}$ value at $0 \mathrm{~h}$ storage was 6.4 , which was higher than that of the other groups. In the SCD $29^{\circ} \mathrm{C}$ groups, $\mathrm{pH}$ values declined rapidly during the $6 \mathrm{~h}$ storage, and the $\mathrm{pH}$ value was lowest at 5.5, after which few changes were observed. In the SCD $17^{\circ} \mathrm{C}$ group, the initial $\mathrm{pH}$ value $(0 \mathrm{~h})$ was 6.3 , which decreased to 6.0 after $2 \mathrm{~h}$ storage and remained constant at around 6.0 during the storage period. In the SA 29 and $17^{\circ} \mathrm{C}$ groups, $\mathrm{pH}$ values were 5.7 and 5.9 at $0 \mathrm{~h}$ storage, respectively. Moreover, $\mathrm{pH}$ values of both groups showed no significant changes during storage. These results suggested that $\mathrm{pH}$ was greatly affected by the high breeding temperature and slaughter method.

\section{Degradation of myofibrillar proteins}

The change in the SDS-PAGE profile of myofibrillar proteins from two slaughter methods with storage time is shown in Fig. 3. For both groups, SDS-PAGE gels showed that $\mathrm{MHC}$ decreased with time during the $24 \mathrm{~h}$ storage. In the SCD $29^{\circ} \mathrm{C}$ group, increases in the 97-, 50-, 42- and $38-\mathrm{kDa}$ bands were observed when the burnt meat appeared

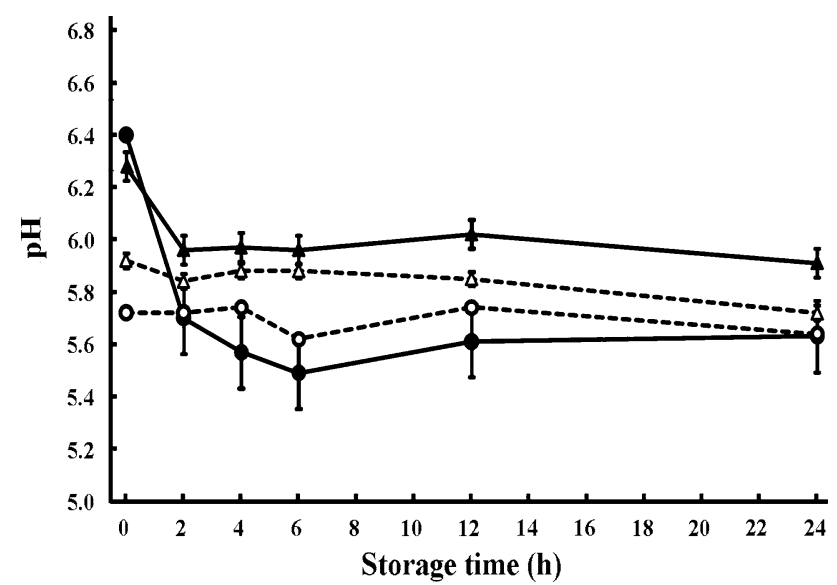

Fig. 2 Changes in ultimate muscle $\mathrm{pH}$ of the ordinary muscle of yellowtail from two breeding temperatures and two slaughter methods during storage at $30^{\circ} \mathrm{C}$. Closed circles SCD $29^{\circ} \mathrm{C}$; open circles SA $29^{\circ} \mathrm{C}$; closed triangles $\mathrm{SCD} 17^{\circ} \mathrm{C}$; open triangles $\mathrm{SA} 17^{\circ} \mathrm{C}$. Data are means $( \pm \mathrm{SD})$ of three replicates 
Fig. 3 SDS-polyacrylamide gel electrophoresis (5-15\% gels) of myofibrillar protein degradation on yellowtail ordinary muscle from two slaughter methods in summer (breeding temperature is $29^{\circ} \mathrm{C}$ ) during storage at $30^{\circ} \mathrm{C}$. Lanes $M$ prestained standard marker; $O$ non-storage control; 2-24 storage times. Arrowheads indicate the positions of myosin heavy chain (MHC) and actin. The blank arrows indicate the proteolytic products

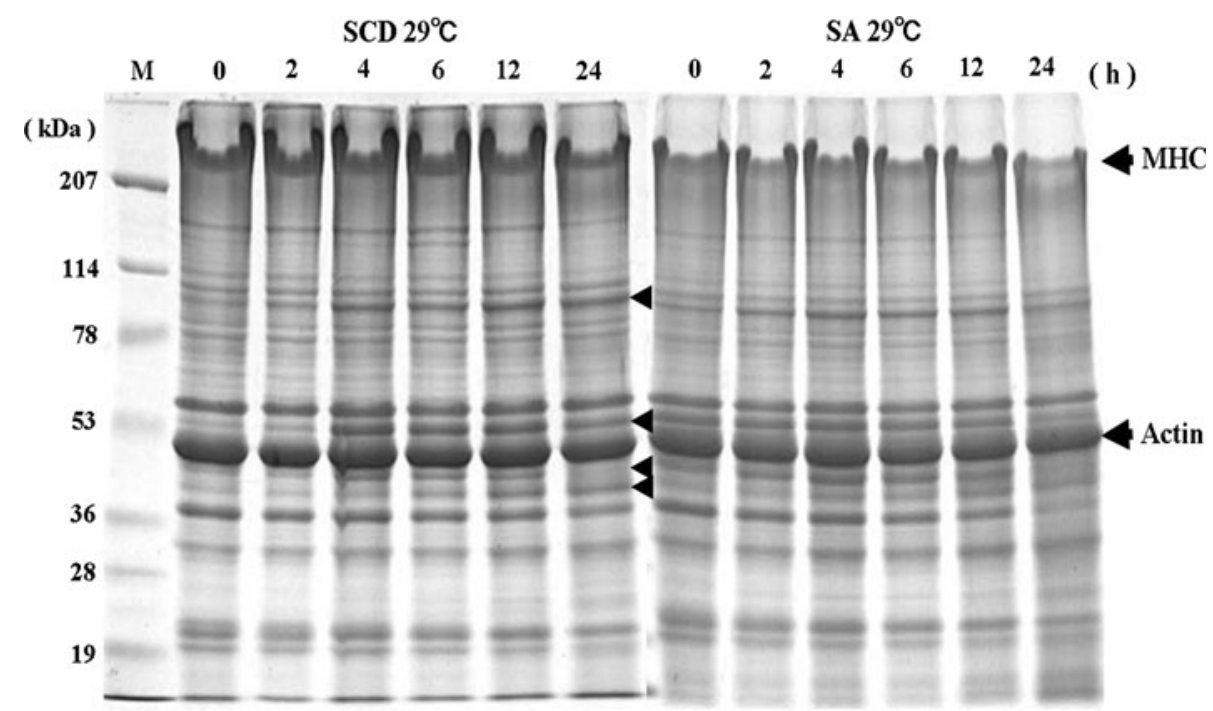

Fig. 4 SDS-polyacrylamide gel electrophoresis (8\% gels) analysis of the inhibitory effect of protease inhibitors on degradation of myofibrillar proteins from yellowtail. Myofibrils were isolated from muscles of the SCD $29^{\circ} \mathrm{C}$ group (a) and $17^{\circ} \mathrm{C}$ group $(\mathbf{b}, \mathbf{c})$ just after slaughter. Myofibrils were dissolved in $50 \mathrm{mM}$ acetic acidsodium acetate buffer ( $\mathrm{pH} 5.8$ ) and different types of inhibitors. Lanes $M$, molecular-weight marker; (1), $0 \mathrm{~h}$; (2) no inhibitor 12 h (control); (3) Pefabloc SC to the final concentration of $5 \mathrm{mM}$; (4) E-64 to $0.01 \mathrm{mM}$; (5) pepstatin A to $0.01 \mathrm{mM}$; (6) EDTA to $5 \mathrm{mM}$; (7) $o$ phenanthroline to $5 \mathrm{mM}$; $(8)$ phosphoramidon to $100 \mu \mathrm{g} / \mathrm{ml}$, respectively, incubated at $30^{\circ} \mathrm{C}$ for $12 \mathrm{~h}$. Arrowheads indicate the positions of myosin heavy chain (MHC) and actin

(b) $\begin{array}{llllllll}\mathrm{M} & 1 & 2 & 3 & 4 & 5 & 6\end{array}$

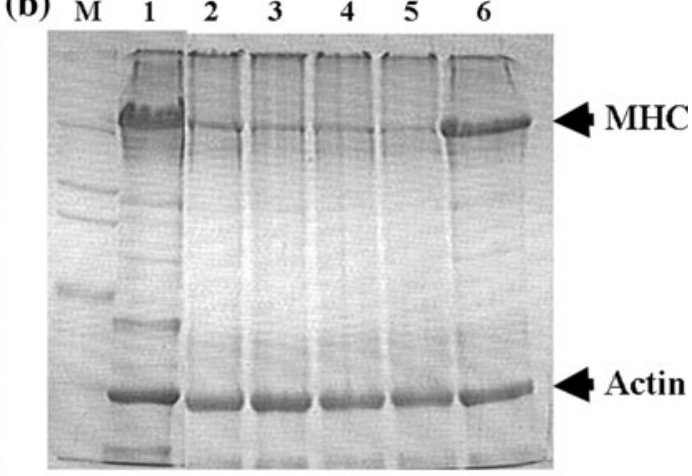

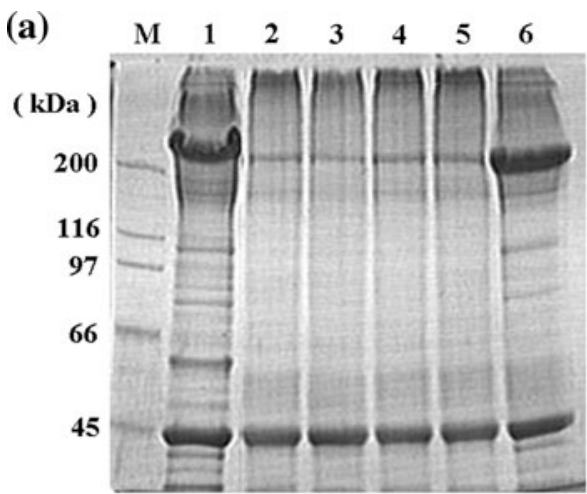

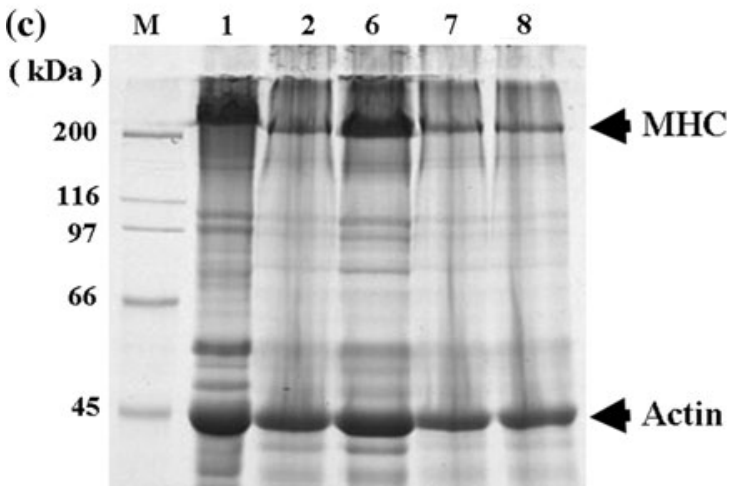

after $4 \mathrm{~h}$. In the SA $29^{\circ} \mathrm{C}$ group, degradation of myofibrillar proteins during storage was faster than that of the SCD $29^{\circ} \mathrm{C}$ group. The $50-\mathrm{kDa}$ band was found in newly slaughtered samples. With the appearance of burnt meat after $2 \mathrm{~h}$, increases in the 97-, 42- and 38-kDa bands were found. In the $17^{\circ} \mathrm{C}$ groups, little degradation was observed during storage, and an increase of $50 \mathrm{kDa}$ was found after $6 \mathrm{~h}$ storage in the SCD group and after $4 \mathrm{~h}$ in the SA group (data not shown). No degradation of actin was observed in any of the groups.
Effect of protease inhibitors on the degradation of myofibrillar proteins

Different protease inhibitors were added to the myofibrils, and their suppressive effects on proteolytic activity are shown in Fig. 4. Compared to the $0 \mathrm{~h}$ group, the control showed decreased intensity of the protein band, completely corresponding to MHC (220 kDa). EDTA, an inhibitor of metalloproteases, completely suppressed the degradation of MHC in comparison to the control (Fig. 4a). Cysteine 
protease inhibitor E-64 and aspartic protease inhibitor pepstatin A both slightly inhibited the degradation of MHC. On the other hand, Pefabloc SC, a serine protease inhibitor, did not show any inhibitory effect on MHC degradation. In Fig. 4b, EDTA completely suppressed the degradation of $\mathrm{MHC}$, and three other protease inhibitors showed no inhibiting effect. In Fig. 4c, the effect of three metalloprotease inhibitors on degradation of myofibrillar proteins is shown. Compared to the control, EDTA completely suppressed the degradation of $\mathrm{MHC}$, while the metalloprotease inhibitors $o$-phenanthroline and phosphoramidon showed no inhibitory effect on MHC degradation. These results suggest that a myofibril-bound EDTA-sensitive protease (MBESP) exists in yellowtail muscle and may have caused the degradation of MHC.

Degradation of myofibrillar proteins at different $\mathrm{pHs}$ and temperatures

The effect of $\mathrm{pH}$ on degradation of myofibrillar proteins by MBESP from yellowtail is shown in Fig. 5a. Compared to the $\mathrm{MHC}$ band at $0 \mathrm{~h}$, the original $\mathrm{MHC}$ bands were thinner at $\mathrm{pH}$ 3.9-6.9. The intensity degradation of MHC was observed at pH 5.0 in Fig. 5a and was inhibited by EDTA
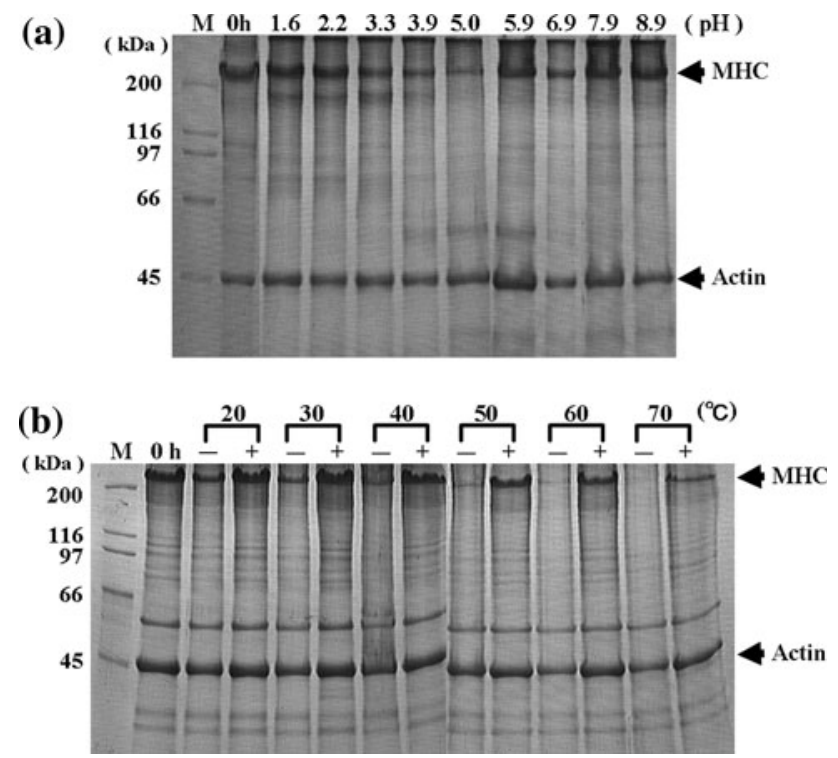

Fig. 5 SDS-polyacrylamide gel electrophoresis (8.5\% gels) analysis of the effect of $\mathrm{pH}$ (a) and temperature (b) on degradation of myofibrillar proteins by myofibril-bound EDTA-sensitive protease (MBESP) from yellowtail. Myofibrils were isolated from the meat of the SCD $17^{\circ} \mathrm{C}$ group just after slaughter. a Myofibrils were incubated with $0.1 \mathrm{M}$ buffer at different $\mathrm{pHs}$ for $12 \mathrm{~h}$ at $37^{\circ} \mathrm{C}$. b Myofibrils were incubated with $0.1 \mathrm{M}$ acetic acid-sodium acetate buffer $(\mathrm{pH} 5.0)$ at different temperatures for $12 \mathrm{~h}$, incubation with EDTA $(+)$ or without EDTA (-). Lanes $M$ molecular-weight marker; 0 h: non-incubation. Arrowheads indicate the positions of myosin heavy chain (MHC) and actin (data not shown). The effect of temperature on degradation of myofibrillar proteins by MBESP is shown in Fig. 5 b. MHC was degraded to some degree at $20-70^{\circ} \mathrm{C}$. At $50-60^{\circ} \mathrm{C}$, the degradation of $\mathrm{MHC}$ was strong, but this was inhibited by EDTA. Degradation of MHC was also observed at $70^{\circ} \mathrm{C}$ when incubated without EDTA, but degradation was partially suppressed by EDTA.

\section{Discussion}

In this study, the authors demonstrated that the appearance of burnt meat was accompanied by the degradation of MHC and changes in protein profile. Moreover, protease inhibitors E-64, pepstatin A, Pefabloc SC, o-phenanthroline and phosphoramidon all showed no significant inhibitory effect on the suppression of MHC degradation. In contrast, EDTA, an inhibitor of metalloproteases, completely suppressed the degradation of MHC.

Muscle color $\left(L^{*}\right)$ and ultimate muscle $\mathrm{pH}$ are useful as indicators for assessment of burnt meat [1]. When the fish was slaughtered and stored at $30^{\circ} \mathrm{C}$, burnt meat (with muscle color parameter, $L^{*} \geq 55$ ) was observed after $2 \mathrm{~h}$ storage in the SA $29^{\circ} \mathrm{C}$ group, and after $4 \mathrm{~h}$ in SCD $29^{\circ} \mathrm{C}$ and SA $17^{\circ} \mathrm{C}$ groups. By contrast, the meat was normal in the $\mathrm{SCD} 17^{\circ} \mathrm{C}$ group until after $12 \mathrm{~h}$ storage (Fig. 1). These results imply that temperature and the slaughter method play an important role in the occurrence of burnt meat in yellowtail. This finding is consistent with the report by Mora et al. [1].

In this study, the muscle $\mathrm{pH}$ value ranged from 5.5 to 5.9 when the burnt meat appeared (Fig. 2). The $\mathrm{pH}$ values of the $29^{\circ} \mathrm{C}$ group were lower than those of the $17^{\circ} \mathrm{C}$ group. In the SCD groups, $\mathrm{pH}$ values dramatically decreased during the initial stage of storage. The lower muscle $\mathrm{pH}$ can lead to negative effects (such as poor liquid-holding capacity and a rapid degradation of the muscle proteins) on the quality of fish according to several reports [17, 25, 26]. During the culture of some fishes, intensive feeding increased the glycogen level in the muscle [17, 25, 26]. Post-mortem, high muscle temperature caused rapid glycolysis, which increased the lactic acid content and consequently caused the drop in $\mathrm{pH}[1,27]$. The phenomenon was similar to previous reports on burnt meat of tuna and pork [27-31].

The present result clearly showed a $\mathrm{pH}$-dependent degradation of $\mathrm{MHC}$ in yellowtail burnt meat (Fig. 3). Yu and Lee [32] suggested that in bovine muscle, $\mathrm{pH}$ dictated the degradation of myofibrillar proteins in the post-mortem muscle. A previous study demonstrated that myosin has an isoelectric point at $\mathrm{pH} 5.5$ [17], and proteins may be more susceptible to degradation at $\mathrm{pH}$ close to their isoelectric points $[17,33]$. Therefore, this may also contribute to the 
increased degradation at the lower $\mathrm{pH}$ [17]. With the appearance of burnt meat, MHC was degraded, and some changes in 97-, 50-, 42- and 38-kDa bands of the myofibrils were observed. These protein bands may be the proteolytic products of myofibrils in yellowtail burnt meat. A similar phenomenon was also observed in PSE meat of pork [34].

Previous studies demonstrated that the degradation of MHC by endogenous protease, especially myofibril-bound serine proteinase (MBSP), is generally regarded as the main cause of the modori phenomenon [20]. When this study was conducted, it was expected that the degradation of MHC in cultured yellowtail burnt meat may also be caused by MBSP.

In order to identify which protease caused the degradation of MHC in yellowtail burnt meat, specific protease inhibitors, including Pefabloc SC (MBSP inhibitor), were added to the myofibrils, and their inhibiting effects on hydrolytic activity were investigated (Fig. 4). EDTA was found to completely suppress the degradation of MHC, while the other metalloprotease inhibitors $o$-phenanthroline and phosphoramidon showed no inhibitory effect on MHC degradation. These results suggest that MBESP might be associated with myofibrils of yellowtail muscle. In addition, E-64 and pepstatin A had weak inhibiting effects on MHC degradation, indicating that acid cysteine proteases (cathepsins B and L) and aspartic acid protease (cathepsin D) are possibly involved in MHC degradation during storage. In contrast, Pefabloc SC, an inhibitor for serine proteases, did not show any inhibitory effect on MHC degradation, suggesting that the MBSP may not exist in yellowtail muscles or the activity of MBSP may be weak.

Although MBSP were not obviously observed in yellowtail muscles, the existence of MBSP has been identified in some kinds of animals. For example, Hori et al. [35] purified chymotrypsin-type serine proteinases from the skeletal muscle of the mouse. Sangorrin et al. [36] partially purified a trypsin-type serine proteinase from the skeletal muscle of the mouse. Tshidino et al. [37] partially purified a MBSP from ostrich Struthio camelus skeletal muscle. MBSPs were also detected in several fishes, including carp Cyprinus carpio [10, 20], wanieso lizardfish Saurida wanieso [20], brushtooth lizardfish Saurida undosquamis [38] and crucian carp Carassius auratus [11].

In this study, we found that MBESP may exist in burnt meat of cultured yellowtail, and this may be involved in the degradation of MHC. In our previous studies on myofibril proteolysis, the degradation of MHC in pork, fowl and some fishes, such as red stingray and puffer fish, was inhibited by the EDTA (data not shown). This suggests that MBESP may also exist in some kinds of animals. Nevertheless, this warrants further investigation.

The degradation of myofibrils by MBESP at different $\mathrm{pHs}$ and temperatures was investigated on SDS-PAGE
(Fig. 5). MBESP strongly degraded MHC at pH 5.0 and $50-60^{\circ} \mathrm{C}$. Very little change in $\mathrm{MHC}$ at $\mathrm{pH} 6.9$ indicated that the neutral proteases are not important for this breakdown. In carp Cyprinus carpio and wanieso lizardfish Saurida wanieso, the optimum $\mathrm{pH}$ and temperature of the MBSP were $\mathrm{pH} 7.0-8.0$ and $55-60^{\circ} \mathrm{C}$, respectively [20, 39]. Both MBSP and MBESP have optimum temperatures of around $50-60^{\circ} \mathrm{C}$ for degradation of MHC. MBSP had been reported to cleave MHC at neutral $\mathrm{pH}$ [10], while MBESP degraded MHC in acid in the present study. Therefore, the degradation of myofibrillar proteins in burnt meat of cultured yellowtail may be caused by MBESP.

To clarify the involvement between the degradation of myofibrillar proteins in cultured yellowtail burnt meat and MBESP, the authors are now trying to isolate this protease from myofibrils and then analyze its enzymatic characteristics.

Open Access This article is distributed under the terms of the Creative Commons Attribution Noncommercial License which permits any noncommercial use, distribution, and reproduction in any medium, provided the original author(s) and source are credited.

\section{References}

1. Mora DA, Hamada Y, Okamoto A, Tateishi A, Tachibana K (2007) Characteristics of burnt meat in cultured yellowtail Seriola quinqueradiata. Fish Sci 73:651-659

2. Konagaya S, Konagaya T (1979) Acid denaturation of myofibrillar protein as the main cause of formation of "yake-niku", a spontaneously done meat, in red meat fish. Nippon Suisan Gakkaishi 45:245

3. Cramer JL, Nakamura RM, Dizon AE, Ikehara WN (1981) Burnt tuna: conditions leading to rapid deterioration in the quality of raw tuna. Mar Fish Rev 43:12-16

4. Davie P, Sparksman RI (1986) Burnt tuna: an ultrastructural study of postmortem changes in muscle of yellowfin tuna (Thunnus albacores) caught on rod and reel and southern bluefin tuna (Thunnus maccoyii) caught on handline or longline. J Food Sci 51:1122-1128

5. Mishima T, Nonaka T, Okamoto A, Tsuchimoto M, Ishiya T, Tachibana K, Tsuchimoto M (2005) Influence of storage temperatures and killing procedures on post-mortem changes in the muscle of horse mackerel caught near Nagasaki Prefecture, Japan. Fish Sci 71:187-194

6. Wilson GGIII, Van Laack RLJM (1999) Sarcoplasmic proteins influence water-holding capacity of pork myofibrils. J Sci Food Agric 79:1939-1942

7. Wang H, Pato MD, Shand P (2005) Biochemical properties of natural actomyosin extracted from normal and pale, soft, and exudative pork loin after frozen storage. J Food Sci 30C:313-320

8. Van Laack RLJM, Liu CH, Smith MO, Loveday HD (2000) Characteristics of pale, soft, exudative broiler breast meat. Poultry Sci 79:1057-1061

9. Konagaya S, Konagaya $T$ (1978) Denaturation at moderate temperatures of myofibrillar protein of red-meat fish: a possible cause of yake-niku. Bull Tokai Res Lab 96:67-74 (in Japanese with English abstract)

10. Cao MJ, Hara K, Osatomi K, Tachibana K, Izumi T, Ishihara T (1999) Myofibril-bound serine proteinase (MBP) and its degradation of myofibrillar proteins. J Food Sci 64:644-647 
11. Cao MJ, Jiang XJ, Zhong HC, Zhang ZJ, Su WJ (2006) Degradation of myofibrillar proteins by a myofibril-bound serine proteinase in the skeletal muscle of crucian carp (Carasius auratus). Food Chem 94:7-13

12. Aranishi F, Ogata H, Hara K, Osatomi K, Ishihara T (1998) Susceptibility of opioid peptides and myofibrillar proteins to carp cathepsin L. J Agric Food Chem 46(2):388-392

13. Ogata H, Aranishi F, Hara K, Osatomi K, Ishihara T (1998) Proteolytic degradation of myofibrillar components by carp cathepsin L. J Sci Food Agric 76:499-504

14. An H, Weerasinghe V, Seymour TA, Morrissey MT (1994) Cathepsin degradation of Pacific whiting surimi proteins. J Food Sci 59(5):1013-1017

15. Nakamura S, Ogawa M, Saito M, Nakai S (1998) Application of polymannosylated cystatin to surimi from roe-herring to prevent gel weaking. FFBS Lett 427:252-254

16. Godiksen H, Morzel M, Hyldig G, Jessen F (2009) Contribution of cathepsins B, L and D to muscle protein profiles correlated with texture in rainbow trout (Oncorhynchus mykiss). Food Chem 113(4):889-896

17. Wang PA, Vang B, Pedersen AM, Martinez I, Olsen RL (2011) Post-mortem degradation of myosin heavy chain in intact fish muscle: Effect of $\mathrm{pH}$ and enzyme inhibitors. Food chem 124:1090-1095

18. Kinoshita M, Toyohara H, Shimizu Y (1990) Purification and properties of a novel latent proteinase showing myosin heavy chain degrading activity from threadfin-bream muscle. J Biochem 107:587-591

19. Yanagihara S, Nakaoka H, Hara K, Ishihara T (1991) Purification and characterization of serine proteinase from white croaker skeletal muscle. Nippon Suisan Gakkaishi 57:133-142

20. Cao MJ, Osatomi K, Hara K, Ishihara T (2000) Identification of a myofibril-bound serine proteinase (MBSP) in the skeletal muscle of Lizard fish Saurida wanieso which specifically cleaves the arginine site. Comp Biochem Physiol 125B:255-264

21. Du XL, Du CH, Liu GM, Wang XC, Hara K, Su WJ, Cao MJ (2010) Effect of a myofibril-bound serine proteinase on the deg of giant protein titin and nebulin. J Food Biochem 34:581-594

22. Hunt RWG (1970) The specification of colour appearance. 1. Concepts and terms. Color Res Appl 2:55-68

23. Lowry OH, Rosebrough NJ, Farr AL, Randall RJ (1951) Protein measurement with the Folin phenol reagent. J Biol Chem 193:256-275

24. Laemmli UK (1970) Cleavage of structural proteins during the assembly of head of bacteriophage T4. Nature 277(5259):680-685

25. Ang JF, Haard NF (1985) Chemical composition and postmortem changes in soft textured muscle from intensely feeding Atlantic cod (Gadus morhua L.). J Food Biochem 9(1):49-64

26. Ofstad R, Egelandsdal B, Kidman S, Myklebust R, Olsen RL, Hermansson AM (1996) Liquid loss as effected by post-mortem ultrastructural changes in fish muscle: Cod (Gadus morhua L.) and salmon (Salmo salar). J Sci Food Agric 71(3):301-312

27. Ochiai Y (2010) Changes in quality and denaturation of sarcoplasmic protein components in the burnt meat of bluefin tuna Thunnus thynnus orientalis. Nippon Suisan Gakkaishi 76(4):695-704 (in Japanese with English abstract)

28. Oka H, Kazuhito O, Ninomiya J (1990) Changes in texture during cold storage of cultured yellowtail meat prepared by different killing methods. Nippon Suisan Gakkaishi 56:1673-1678 (in Japanese with English abstract)

29. Fischer K, Augustini C (1977) Stadien der postmortalen glykogenolyse bie unterschiedlichen $\mathrm{pH}_{1}$-Werten in scheweinefleich. Die Fleishwirtschaft 6:1191-1194 (in German)

30. McCurdy RD, Barbut S, Quinton M (1996) Seasonal effect on pale soft exudative (PSE) occurrence in young turkey breast meat. Food Res Int 29:363-366

31. Warriss PD, Brown SN, Pasciak P (2006) The colour of the adductor muscle as a predictor of pork quality in the loin. Meat Sci 73:565-569

32. Yu LP, Lee YB (1986) Effects of postmortem $\mathrm{pH}$ and temperature on bovine muscle structure and meat tenderness. J Food Sci 51:774-780

33. Dice JF, Goldberg AL (1975) Relationship between in vivo degradative rates and isoelectric points of proteins. Proc Natl Acad Sci USA 72(10):3893-3897

34. Laville E, Sayd T, Sante'-Lhoutellier V, Morzel M, Labas R, Franck M, Chambon C, Monin M (2005) Characterisation of PSE zones in semimembranosus pig muscle. Meat Sci 70:167-172

35. Hori S, Ohtani S, Hori C, Nokihara K (1998) Purification and characterization of myonase from X-chromosome linked muscular dystrophic mouse skeletal muscle. J Biochem (Tokyo) 123:650-658

36. Sangorrin MP, Martone CB, Sanchez JJ (2002) Myofibril-bound serine protease and its endogeneous inhibitor in muscle: extraction, partial characterization and effect on myofibrils. Comp Biochem Physiol 131B:713-723

37. Tshidino SC, Krause J, Adebiyi AP, Muramoto K, Naude RJ (2009) Purification and partial characterization of a myofibrilbound serine protease from ostrich skeletal muscle. Comp Biochem Physiol 154B:229-234

38. Ohkubo M, Miyagawa K, Osatomi K, Hara K, Nozaki Y, Ishihara $\mathrm{T}$ (2004) A novel serine protease complexed with $\alpha_{2}$-macroglobulin from skeletal muscle of lizard fish (Saurida undosqyamis). Comp Biochem Physiol 139B:637-647

39. Osatomi K, Sasai H, Cao MJ, Hara K, Ishihara T (1997) Purification and characterization of myofibril-bound serine proteinase from carp Cyprinus carpio ordinary muscle. Comp Biochem Physiol 116B:183-190 